\title{
ЕТИЧКИ ПРИНЦИПИ И АКАДЕМСКИ ИНТЕГРИТЕТ У ПРОЦЕСУ ИЗРАДЕ НАУЧНОИСТРАЖИВАЧКИХ РАДОВА
}

АПСТРАКТ: Процес израде научног рада је дуг и на том путу може доћи до повреде етичких начела у свакој од фаза израде уколико се не познаје или намерно занемари етички кодекс. Најчешће и најтеже повреде етичког кодекса су плагирање, лажно ауторство, измишљање и кривотворење резултата и аутоплагирање. У овом раду ће бити представљена етичка начела којих се треба придржавати у процесу израде научноистраживачког рада како не би дошло до урушавања академског кредибилитета и интегритета истраживача. Навођење етичких начела засновано је на важећим правилницима у Републици Србији који су донети на нивоу целе државе и високошколских установа чија је обавеза била да своја акта ускладе са Основама за кодекс о академском интегритету на високошколским установама у Републици Србији, који је усвојио Национални просветни савет 2016. године.

Кључне речи: етичка начела, високошколске установе, фазе израде научног рада, цитирање, плагијат, аутоплагијат, лажно ауторство, измишљање и кривотворење резултата.

\section{ETHICAL PRINCIPLES AND ACADEMIC INTEGRITY IN PREPARING SCIENTIFIC RESEARCH PAPERS FOR PUBLICATION}

ABSTRACT: The process of writing scientific and research papers is rather long and ethical principles can be violated in each of the phases if the code of ethical behaviour is not known or is intentionally neglected. The most common and serious offences of the code are plagiarism, false authorship, fabrication and falsification of results, and self-plagiarism. This paper will present the ethical principles that should be observed in the process of writing scientific research papers in order to avoid the undermining and damaging the researcher's academic credibility and integrity. These principles are based on valid regulations in the Republic of Serbia adopted at the level of the entire country and at the level of higher education institutions, whose obligation was to harmonize their acts with the Fundamentals of the Code of Academic Integrity at higher education institutions in the Republic of Serbia, adopted by National Education Council in 2016.

Key words: ethical principles, higher education institutions, stages of writing a scientific paper, citation, plagiarism, auto-plagiarism, false authorship, fabrication and falsification of results. 


\section{1. УВОД}

Последњих година смо сведоци неакадемског понашања и кршења етичких принципа при изради научних радова који су изазвали велику пажњу јавности, а научну заједницу представили у негативном смислу. Један од недавних примера из 2019. године био је докторат министра финансија Синише Малог за који је Одбор за професионалну етику Универзитета у Београду утврдио да је плагијат, што је за последицу имало поништење титуле доктора наука коју је Синиша Мали стекао (Одбор за професионалну етику 2019) ${ }^{1}$. Јавност углавном није претерано заинтересована за стање у академском свету, али писање у медијима о случају плагијата у раду политичара није могло да остане незапажено. Поред Синише Малог, под оптужбама за плагијат био је и Небојша Стефановић, министар полиције, као и Александар Шапић, председник општине Нови Београд (Комисија је касније утврдила да докторат Небојше Стефановића није плагијат). Плагијати међу политичарима, међутим, нису својствени само нашој земљи. Као можда најпознатији случај у скорије време издвајамо случај и министра одбране Немачке, барона Карла Теодора Гутенберга, који се због утврђеног плагијата 2011. године одрекао докторске титуле и дао оставку на функцију (Филиповић 2011). У Немачкој је забележен и случај Анете Шаван, министарке образовања, којој је Универзитет Диселдорф одузео докторску титулу 2013. године због неадекватног цитирања у докторској дисертацији тридесет три године раније (Рошчић 2013). Што се тиче професора са високошколских установа, ситуација није много боља - у тренутку писања овог рада на сајту Универзитета у Београду, Одбора за професионалну етику, стоје три јавне осуде због плагирања и пет решења о неакадемском понашању само у последње две године (решења се односе на поступања по питању неакадемског понашања).

Намеће се питање да ли је оваква појава неакадемског понашања настала у последње две деценије, како је могуће да се дешава и којих моралних начела треба истраживач да се придржава како његов академски интегритет не би био угрожен. Откривање плагијата постало је много лакше због употребе адекватних софтвера за утврђивање плагијата, приступа

\footnotetext{
${ }^{1}$ Овај случај још увек није добио разрешење. Управни суд је у јуну 2021. године поништио решење Одбора за професионалну етику Универзитета у Београду и предмет је враћен Одбору на поновно одлучивање.
} 
интернету и репозиторијумима мастер радова и докторских дисертација. Транспарентност радова на овај начин омогућила је свима трајни увид јавности, али с друге стране и много лакши приступ туђим радовима него што је то раније био случај - када је за сваку библиографску јединицу требало отићи у библиотеку. Из тог разлога је питање етичких начела све актуелније и добија на значају. Изазови су превелики; свесно или несвесно, истраживачи и научни радници могу да се нађу у незгодној ситуацији због преузимања заслуга.

У овом раду ће бити речи о етичким принципима научног сазнања као здравој основи за бављење квалитетним научноистраживачким радом. Кроз анализу фаза у истраживачком процесу, представићемо основне појмове битне за поштовање ових начела: ауторска права, интелектуална својина, плагијат, лажно ауторство и аутоплагирање. Направићемо у оквиру сваке фазе и посебан осврт на представљање докумената и закона који регулишу ову област на нивоу државе и универзитета. На крају рада ћемо укратко представити етичке кодексе на државним универзитетима у Србији и представити пример добре праксе за упознавање са овом облашћу.

\section{2. ЕТИЧКИ ПРИНЦИПИ И АКАДЕМСКИ ИНТЕГРИТЕТ НАУЧНОГ САЗНАЬА КАО ПРЕДМЕТ ИСТРАЖИВАЬА}

Академски интегритет представља етички кодекс у складу са којим треба да се понашају припадници академске заједнице. То је скуп вредности и принципа којима се унапређују активност и делатност високошколске установе и универзитета у целини (Бјелобаба 2019). Међународни центар за академски интегритет дефинише академски интегритет као посвећеност следећим основним вредностима: искреност, поверење, правичност, поштовање, одговорност и храброст (Основне вредности академског интегритета 2020: 2). Лексема интегритет потиче од латинске речи integritas и може означавати не само потпуност, недељивост, целовитост, већ и лично поштење, честитост, часност, независност, исправност и непорочност, као и приврженост одређеним вредностима и понашању. У усвојеним кодексима о академском интегритету на универзитетима у Србији наводи се да академски интегритет представља честитост и да се очекује од

„чланова академске заједнице у обављању професионалног рада и испуњавању академских дужности, током научног и наставног рада, да негују и штите академску честитост тако што се њихово деловање заснива на самосталном научном и наставном раду, спровођењу оригиналних (нових) 
научних истраживања, објављивању властитих резултата рада, строгом поштовању ауторских права других, као и другим академским обавезама предвиђеним Кодексом” (Кодекс о академском интегритету 2020, чл. 1).

Кршење академског интегритета може имати разне облике, а један од најтежих преступа јесте плагијат.

Ако пођемо од етимологије речи, етички принципи су принципи или начела који спадају у домен етике (грч. ethikos), односно науке о моралу. Предмет етике је морална пракса и примена моралних начела (норми правилног и моралног деловања) у животу, а у нашем случају се мисли на примену моралних начела у научноистраживачком раду. Етичка начела научноистраживачке делатности су примена етике научноистраживачког рада, у складу са принципима добре научне праксе, и одговорности научника за последице свог рада (Закон о научноистраживачкој делатности, чл. 5). Основни здраворазумски етички принципи којима треба да се воде истраживачи су: објективност, непристрасност, јавност и проверљивост истраживања које спроводе. Међутим, листа је дужа и заправо регулисана правилником. У Кодексу понашања у научноистраживачком раду наводе се следећа начела: искреност, поузданост, објективност, непристрасност и независност, отворена комуникација, вођење бриге о учесницима и субјектима истраживања, исправност у навођењу референци и одговорност према будућим генерацијама (Кодекс понашања у научноистраживачком раду 2018: 2). Поред ових основних, постоје и друга начела о којима ће бити речи у даљем тексту и имају везе са моралним понашањем које не може увек законом да се регулише (као што је постојање савести у раду). Обрадићемо их кроз анализу фаза у истраживачком поступку: у фази прикупљања литературе, у фази коришћења литературе, у фази нацрта истраживања, у приступању и прикупљању података, у фази анализе и интерпретације резултата (према Ткалац Верчич, Синчић Ћорић, \& Полошки Вокић 2010: 5). У овом раду ћемо обрадити још једну фазу у истраживачком процесу - фазу обликовања и публикације научног рада².

\footnotetext{
2 Под научним радом се у овом раду подразумевају они радови у којима се излажу главни резултати научноистраживачког рада који представљају допринос развоју науке.
} 


\section{1. Етички принциии у фази прикупљаға литературе}

Прва фаза којом почиње сваки научноистраживачки подухват јесте фаза прикупљања литературе. Ткалац Верчић и др. (2010) прву и другу фазу наводе заједно; међутим, сматрамо да их у овом раду треба одвојити, с обзиром на то да можемо бити ограничени ауторским правом да користимо туђ материјал. У овом потпоглављу ћемо објаснити у којим случајевима може доћи до такве ситуације. Интернет је умногоме допринео лакшем приступању литератури. Сада је много једноставније доћи до библиографских јединица за које је некад било потребно ићи у библиотеку или их тражити преко међубиблиотечке позајмице. Поред званичних електронских издања која се нуде у дигиталним библиотекама, истраживачима су доступни и разни репозиторијуми научних радова и радови до којих се лако долази претраживањем, пошто су објављени у часописима са отвореним приступом. Међутим, и даље има научних радова до којих је тешко доћи, а неретко захтевају и плаћање приступа. На интернету углавном постоји решење и за такве ситуације: неки веб-сајтови нуде услугу „откључавања” научних радова из часописа затвореног приступа (нпр. https://sci-hub.se) или се на неким сајтовима могу бесплатно преузети целе књиге у пе-де-еф или доц формату (нпр. https://vk.com/). Оваква пракса залази у домен интелектуалне својине и кршења ауторског права. Аутори књига имају право на економско искоришћавање дела стављањем тог дела у промет и добијају накнаду за то. Уколико се омогући слободна и неконтролисана дистрибуција дела путем интернета, аутор неће добити одговарајућу накнаду за свој труд и рад. Једино аутор има искључиво право да другоме дозволи или забрани бележење и умножавање свог дела у целости или делимично, било којим средствима, у било ком облику, на било који трајни или привремени, посредни или непосредни начин (Закон о ауторским и сродним правима 2018, чл. 22). Неовлашћено дистрибуирање није законом дозвољено и санкцијама подлеже свака особа која пусти у промет ауторско дело. С друге стране, није етички бесплатно преузимање ауторских дела путем сајтова који се баве пиратеријом.

Поред моралних задршки у вези са преузимањем нечијег ауторског дела са пиратских сајтова, имамо и нека блага законска ограничења у коришћењу литературе. Иако то није уобичајена пракса, постоје дела која се не смеју прерађивати већ само користити у оригиналном облику. Оваква ситуација регулисана је применом отворених међународних правних стандарда - Кријетив комонс (Creative Commons) (CC). Најстрожа лиценца је 
Ауторство - Некомерцијално - Без прерада. Њом аутор дела дозвољава само преузимање и дистрибуцију дела, ако/док се правилно назначава име аутора, без икаквих промена дела и без права комерцијалног коришћења датог дела. Уколико истраживач пронађе такво дело, $C$ стандарди му налажу да сме само да га цитира, а не и парафразира, сумира закључке или преузима идеје одатле (више о овим лиценцама у пододељку Етички принципи у фази обликовања и публикачије научног рада).

\section{2. Етички принщипи у фази коришћења литературе (писање рада)}

Након што истраживач одабере литературу са којом ће радити, следи фаза коришћења литературе. Најбитнији аспект у овом делу је цитирање. У наведеном примеру Синише Малог са почетка рада видимо грешку у овој фази, јер аутор дисертације преузете делове туђег рада није на одговарајући начин навео (није навео извор).

Цитирање представља дословно навођење речи, идеја или ставова других аутора у сопственом раду. За сваки научноистраживачки процес цитирање је од изузетне важности - представља императив у научном раду али увек треба имати у виду да су интелектуално власништво и ауторска права област која је прилично регулисана законом. Како цитирање не би прешло у плагијат или аутоплагијат, потребно је поштовати правила цитирања која су у суштини веома једноставна - укратко, увек треба навести аутора дела прво одмах у загради након цитата (цитирање унутар текста), а затим и други пут у библиографским референцама на крају рада. Цитирање унутар текста може бити харвардским (аутор - датум), ванкуверским (нумеричким) или мешовитим стилом (нумерички у тексту са додељеним бројевима референцама које су сложене по азбуци или абецеди), што углавном зависи од области истраживања (и писања рада). Харвардски стил је карактеристичан за друштвене и хуманистичке науке, док ванкуверски стил преовладава у природним и техничким наукама (Милић 2021: 2). Употреба било ког стила не може бити погрешна, само је од изузетне важности да се правилно цитира туђе дело како рад не би био проглашен плагијатом.

Према Великом речнику страних речи и израза реч плагијат води порекло од латинске речи plagiarius што значи крадљивац, отимач, док се у савременом језику ова реч користи за „уметничко, научно или друго дело настало подражавањем или присвајањем туђе ауторске својине" (Клајн и Шипка 2007: 942). У Основама за кодекс о академском интегритету на 
високошколским установама у Републици Србији дају се јасне дефиниције и одређења плагијата:

„Плагирање је представљање туђих идеја или туђег рада, у целини или деловима, без навођења изворног ауторства или изворника, односно противзаконито присвајање туђих интелектуалних творевина и научних резултата и њихово приказивање као својих [...]"

(Основе за кодекс о академском интегритету на високошколским установама у Републици Србији 2016: 3).

У даљем тексту се појашњава дефиниција навођењем свих ситуација када се може говорити о плагијату. Плагијат није само дословно преузимање делова туђег рада, већ може бити и парафразирање, сажимање и непрецизно цитирање уколико се аутор дела не цитира адекватно. Посебно је интересантан пример парафразирања. Парафразирање представља препричавање, односно прераду текста другим речима, за шта је потребна одређена језичка вештина. То није навођење туђег текста од речи до речи као што је цитирање. Треба задржати смисао из оригинала и рећи то исто на други начин, а често у циљу бољег разумевања. Понекад истраживачи прибегавају парафразирању тако што задрже исти број реченица, а промене само одређене речи из оригинала и употребе синониме. То није добра пракса и треба је избегавати: „Често је много боље под наводницима пренети део оригиналног текста (уз референцирање), него се упустити у неуспело парафразирање" (Јовановић, 2010: 3). За разлику од парафразирања где су текстови сличне дужине, код сажимања или резимирања текст је краћи од оригинала и циљ је преношење главне идеје сопственим речима. Посебну пажњу треба обратити на употребу парафразираних или сажетих цитата са страног језика. Без обзира на чињеницу да најпре имамо превод на српски језик, а затим препричавање или сажимање, неопходно је адекватно навођење референце. Чак и превод директног цитата, уколико га није сам аутор превео и није званично објављен, мора да има потписано име преводиоца који је за ту прилику превео цитат. У сваком случају, и након парафразирања и сажимања треба правилно референцирати оригинално дело.

Поред лошег парафразирања или сажимања, плагијат представља и непрецизно цитирање, које може имати неколико облика. Први је када аутори преузму делове цитата, али не из оригиналног дела, већ од другог аутора који је исто дело цитирао. Цитирање увек мора бити из оригиналног дела, не само због давања заслуга оригиналном аутору за његов рад већ и зато што цитат 
узет из контекста (уколико нисмо прочитали оригинално дело) може да заведе читаоца на неку другу страну или да се злоупотреби (в. Милић 2021).

Специфичну врсту плагијата представља аутоплагијат. Дешава се да се истраживачи годинама баве истом проблематиком и да пишу радове на сличне теме. Неретко се посегне за „рециклирањем” сопственог, раније објављеног рада и преузимањем његових делова. У овој ситуацији важе иста правила за цитирање као и за било ког другог аутора - делови се могу цитирати, парафразирати или сажимати, али уз правилно навођење сопственог рада у референцама. Многи радови су објављени у часописима који имају јасна правила да се делови из тог часописа не смеју преузимати и публиковати, без обзира на то што смо ми сами аутори свог дела. Према Закону о ауторском и сродним правима аутор дела је увек носилац моралних овлашћења (овлашћење да његово име буде назначено уз дело) и имовинскоправних овлашћења, али поред њега ова имовинскоправна овлашћења могу имати и друга лица која су та права стекла (чл. 9). Тако их може имати, на пример, и часопис у ком је претходно објављен наш рад.

\section{3. Етички принциипи у фази нацрта истраживања}

У Основама за кодекс о академском интегритету наводи се такође да плагијат јесте и представљање туђих идеја као сопствених. Овај аспект је битан у фази нацрта истраживања. Туђи истраживачки процеси се не смеју преузимати без навођења извора. Уколико је неко истраживање већ спроведено, а ми га желимо поновити, то јесте дозвољено, али уз назнаку ауторства оригиналног истраживања.

Уколико истраживач сам ради нацрт истраживања, потребно је да води рачуна и о етичности целокупног истраживања: истраживање на деци, особама са посебним потребама или ситуација нарушавања приватности или психичког стања испитаника или употреба животиња у истраживању. Експериментална истраживања на људима или животињама дубоко задиру у етичке дилеме. Здравље, безбедност, добробит заједнице или животна средина никако не треба да буду угрожени. Одговорност у истраживачким поступцима дефинисана је чланом 7. Кодекса понамања у научноистраживачком раду. 


\section{4. Етички принцичпи у фази приступа подащима и прикупљања података}

Прикупљање података је појавом интернета знатно олакшано. Истраживачима су на располагању многи онлајн алати који се могу користити у прикупљању података - као што је то пример са електронским упитником и видео-конференцијским позивом (в. Стојшин 2014). Међутим, приликом приступа подацима и прикупљања података истраживачи треба да буду нарочито опрезни. Ступањем на снагу Опште уредбе о заштити података личности (енгл. General Data Protection Regulation) у Европској унији и Закона о заштити података код нас драстично се мења приступ подацима које истраживачи могу да прикупе и у коју сврху. Од 25. маја 2018. године све установе које прикупљају или чувају личне податке о било коме ко живи у Европској унији, морају бити у складу са Општом уредбом. Општа уредба је документ који је Европски парламент одобрио 14. априла 2016. године, а примењује се од 25. маја 2018. Замењује Директиву o заштити података 95/46 / ЕЦ и осмишљена је да заштити личне податке појединаца у Европској унији. Организације морају добити изричито одобрење за прикупљање и употребу података појединца и повлачење сагласности мора бити подједнако лако као и давање. Уредба се односи на организације свуда у свету које раде са грађанима Европске уније. Такође је важно схватити да универзитети који нуде курсеве преко интернета, посебно на системима за управљање учењем, морају да се ускладе са Општом уредбом.

Општа уредба о заштити података тиче се личних података и заштите грађана Европске уније од злоупотребе и злоупотребе њихових личних података од трећих лица. Предмет Уредбе односи се на обраду личних података и правила која се односе на слободно кретање личних података (Општа уредба о заштити података о личности, чл. 1). У Уредби се лични подаци дефинишу као било које информације о особи које се могу користити за њихову идентификацију, директно или индиректно: име, идентификациони број, подаци о локацији, мрежни идентификатор или један или више фактора специфичних за физички, физиолошки, генетски, ментални, економски, културни или социјални идентитет тог физичког лица (Општа уредба о заштити података о личности, чл. 4). Када говоримо о веб-локацијама и системима за управљање учењем на универзитетима или факултетима, наведена дефиниција се односи на име, адресу е-поште, информације о налогу, фотографију, ај-пи адресу и још много тога. Укључује 
чак и псеудонимне информације ако их је лако дешифровати да би се открио идентитет особе (Љубојевић 2018: 16).

Веома важан аспект примене ове Уредбе односи се на сагласност и информисаност учесника у истраживању. Не само што у домен етичког понашања истраживача спада тражење сагласности од учесника за учешће у истраживању, већ нас и закон на то обавезује. Иако се Уредба односи на грађане Европске уније, Устав Републике Србије и Закон о заштити података личности садрже исте или сличне одредбе.

Кровним законом у Србији, Уставом Републике Србије, инсистира се на заштити података о личности што подразумева прикупљање, држање, обраду и коришћење података о личности. Употреба података о личности мора бити искључиво за сврху за коју су прикупљени, а свако има право да буде обавештен о прикупљеним подацима о својој личности (Устав РС, чл. 42).

Важећи Закон о заштити података о личности донет је 2018. године и њиме се уређује право на заштиту физичких лица у вези са обрадом података о личности и слободни проток таквих података, начела обраде, права лица на које се подаци односе, обавезе руковалаца и обрађивача података о личности, кодекс поступања, пренос података о личности у друге државе и међународне организације, надзор над спровођењем овог закона, правна средства, одговорност и казне у случају повреде права физичких лица у вези са обрадом података о личности, као и посебни случајеви обраде (Сл. гласник РС, бр. 87/2018).

На основу ових закона може се видети да је неопходно да истраживач води рачуна о томе коју врсту података тражи од испитаника, као и да сви испитаници у истраживању морају да дају сагласност за учешће у истраживању. У оквиру сагласности морају јасно да буду обавештени о томе у ком истраживању учествују, о правој сврси и циљу истраживања (начело искрености), колико је предвиђено трајање истраживања, односно колико времена ће одузети испитанику, да ли постоји ризик (истраживање не сме да наноси штету испитаницима), да ли испитаници учествују добровољно или добијају неки вид компензације/надокнаде (у научном раду односи истраживача и испитаника морају бити искључиво на добровољној основи), да могу да одустану од учешћа у сваком тренутку, да ће њихови подаци бити анонимни, односно да ће се обрађивати само за сврху тог одређеног истраживања и да ће се користити само у научне сврхе. Испитаницима треба пружити још неке податке уколико су релевантни за истраживање. На крају 
писмене сагласности је неопходан потпис, док је у електронским упитницима довољно штриклирати одговарајуће поље предвиђено за то.

Оваква законска регулатива довела је у питање неке истраживачке поступке који су се користили до сада, као што је посматрање са потпуним учесником. Посматрање је метода научног прикупљања података која се заснива на опсервацији појава непосредним чулним опажајима (чулом вида, слуха, укуса, мириса, али и доживљавањем) $)^{3}$ и често се користи у социологији, политичкој науци, педагогији и комуникологији. Постоје разне класификације посматрања, а за потребе овог рада издвојићемо директно (непосредно) посматрање, пошто се ту јављају спорни етички моменти. Посматрање се, према раду и улози посматрача, може класификовати на посматрање са учествовањем и посматрање без учествовања. Посматрање са учествовањем се даље може поделити на пет категорија учесника: потпуни учесник, учесник - посматрач, посматрач - учесник, чист посматрач и научни посматрач. Сви ови учесници, осим прве наведене категорије, знају да су посматрани и могу да преузму и улогу посматрача у некима од њих. У посматрању са учествовањем са потпуним учесником имамо ситуацију у којој посматрач (активно) учествује у свим активностима групе, при чему чланови групе нису упознати са његовим намерама, нити знају да су посматрани. Иако делује спорно чињеница да учесници не знају да се врши истраживање, оваква врста поступка је веома битна ради утврђивања неког понашања у затвореним групама и често је од интереса за друштво. Етичка дилема је да ли је оправдано вршити такво истраживање, али се то решава накнадним обавештавањем и накнадном сагласношћу (Миљевић 2007: 226).

Још један важан етички моменат у фази прикупљања података јесте следећи - истраживач треба да буде објективан, непристрастан и независтан у раду, да бележи тачне и потпуне податке и да не буде селективан према подацима у зависности од тога да ли му одговарају или не. Субјективност се често наводи као недостатак посматрања (лична уверења, предиспозиције истраживача, и сл.), али се онда то донекле превазилази техником триангулације, као и спровођењем истраживања у којем учествује више независних стручњака (в. Илић 2016: 17).

\footnotetext{
3 Посматрање као истраживачки поступак се може дефинисати на више начина у зависности са ког становишта се полази. Више о томе у Илић (2016) и Миљевић (2007).
} 
Етички моменти у прикупљању података односе се и на неке технике које истраживачи примењују, као на пример у случају групног интервјуа када се користи оштро испитивање. Према Шојховој (E. Scheuch) типологији научних разговора постоје благо, неутрално и оштро/строго испитивање (Милић 1996/1965: 509). Основна идеја благог испитивања јесте успостављање што приснијег односа испитивача са испитаником и стицање његовог потпуног поверења. Ова врста испитивања се најпре примењивала у психијатрији, а затим су се њиме почели служити психолози, клинички психолози и новинари. Испитивач треба да саслуша испитаника стрпљиво и пријатељски, али на интелигентан и критичан начин. Неутрално испитивање је заправо врста анкетирања које се најчешће примењује у масовним анкетама. То је врста структуираног интервјуа где се читају питања, испитаник одговара и његови одговори се записију. Испитивач је само посредник и не успоставља се приснији однос између њега и испитаника. Строго испитивање личи на истражно-судски поступак. Могуће га је обавити у специјално аранжираним ситуацијама и истраживач може да сучељава учеснике у истраживању, као и њихове раније дате исказе, итд. (Миљевић 2007: 205). Испитаник се подвргава врло строгом испитивању које више личи на полицијско саслушање - питања се постављају отворено, безобзирно и брзо, а испитаник мора одмах да одговори без дужег размишљања, првом асоцијацијом које се сети. Веома је важно у оваквој врсти испитивања добити сагласног испитаника за учешће у истраживању и гарантовати му да се на основу добијених информација неће предузимати никакве друштвене санкције. Због ове друге карактеристике, често се доводи у питање веродостојност података, а такође је неподобно за испитивање дубљих побуда и психичких друштвених последица понашања (Милић 1996/1965: 509).

\section{5. Етички принципи у фази обраде, анализе и интерпретащије резултата}

Прикупљени подаци у истраживачком процесу нису довољни сами по себи, већ их је неопходно обрадити како би се на основу резултата донели закључци. Велики проблем у обради података, нарочито истраживачима из области друштвених и хуманистичких наука, представља статистичка обрада података. На пример, на филолошким смеровима у Србији у курикулумима нема предмета Статистика, нити се елементи обраде података обрађују у оквиру других предмета као што је Методологија научних истраживања. Истраживачима из ових области преостаје да се самоиницијативно додатно 
образују на овом пољу или да ангажују статистичара или агенцију за обраду података. Уколико је ово друго случај, треба то навести у раду. С друге стране, учешће трећег лица треба свести на саму обраду података, док анализа и интерпретација резултата представљају искључиво рад истраживача (Ткалац Верчић и др. 2010: 6)

Приликом обраде података, као и у фази прикупљања, треба задржати објективност и непристрасност и не сме доћи до „фризирања” резултата како би се добили бољи резултати. Интерпретација резултата и доношење закључака треба такође да буду објективни, са критичким освртом на све елементе који могу бити спорни или утичу на исход истраживања. Нису дозвољени ни фалсификовање (изостављање или промена података како би се подржала нека тврдња, хипотеза или податак), нити фабриковање (измишљање података или извора), тј. кривотворење или измишљање резултата.

У приказивању резултата истраживања савремени програми којима се обрађују резултати (SPSS, R) нуде богат избор визуелног приказа: разне врсте дијаграма (кружни, стубичасти, штапићасти, линијски, хистограми), табела, графикона, бокс плота (box plot). Сматра се да не треба приказивати исте резултате и табеларно и графички како би се добило на броју страна, те овде предност има графички приказ (Јовановић 2010: 5).

Често се дешава да долази до злоупотребе резултата истраживања. Измишљање и кривотворење резултата представља један од најтежих облика превара у науци, а дефинише се као манипулисање предметом, опремом или процесом истраживања како би резултати научног истраживања били намерно подешени или тенденциозно протумачени (Кодекс понашања у научноистраживачком раду 2018, чл. 14). Овакве појаве су могуће када се истраживање користи за учвршћивање средства експлоатације или неке политике. Изузетно су контроверзна медицинска и фармацеутска истраживања због којих је дошло до пораста теорија завере. Најпознатије истраживање овог типа је оно о утицају ММР вакцине на појаву аутизма код деце, које је спровео Ендрју Вејкфилд (Andrew Wakefield), a 1998. године га и објавио у часопису Лансет (The Lancet). Раскринкавање поменутог рада започело је истрагом новинара Брајана Дира (Brian Deer) који је утврдио да је Вејкфилд био у сукобу интереса, манипулисао доказима и прекршио многе друге етичке кодексе (Дир 2021). Чланак је 2010. године у потпуности повучен, Ендрју Вејкфилд је изгубио лекарску лиценцу, али последице његовог неетичког понашања се и даље осећају. 
Проверљивост спада у основне етичке принципе научног сазнања. У случају истраживања Ендрјуа Вејкфилда, ниједно касније спроведено истраживање тог типа није успело да докаже везу између ММР вакцине и аутизма. Често истраживачи преузимају нацрт другог истраживања - што је дозвољено уз одговарајуће референцирање - и пожељно како би се потврдили претходно добијени резултати. Уколико се новим истраживањима потврди и докаже оригинално истраживање, можемо говорити о начелу проверљивости. Раније споменут истраживачки поступак - непосредно посматрање са учешћем - такође не испуњава начело проверљивости, јер је немогуће поновити идентичне услове и ученике. Велики допринос проверљивости даје транспарентност рада и потпуна јавност свих саставних делова истраживачког поступка (начело јавности).

\section{6. Етички принциипи у фази обликовања и публикащчје научног рада}

Када су у питању захтеви за обликовање научног рада, припрема рада за часопис се углавном одвија према упутствима за ауторе које часопис задаје. Истраживач има врло малу слободу у обликовању текста. Ситуација је мало другачија када су у питању семинарски и мастер радови и докторске дисертације где је истраживачима дата већа слобода у обликовању текста. Треба споменути ситуације када се, због захтеваног броја страна, прибегава фонту који даје „веће” карактере и тиме повећава обим рада, а заправо се не мења ништа суштински. Стандард за израду радова је фонт Times New Romanu, величине 12 pt. Уколико бисмо овај рад пребацили у фонт Ariel број страна би се повећао за две. Постоји још један начин за повећање броја страна - у питању је већи проред између пасуса. Уколико је рад обликован блок стилом за писање (нема увученог првог реда), тада је не само дозвољен, већ и неопходан већи проред. Уколико је рад писан зупчастим стилом (када је прва реченица увучена као што је то случај у овом раду), онда никако није дозвољено правити веће прореде између пасуса. За овакво понашање не постоје законске санкције, али треба да постоји савест као морално начело код студената и истраживача да се број страна не повећава на овај начин. Прецизно упутство за техничко обликовање рада (са предвиђеним/ограниченим бројем речи и карактера) у потпуности отклонило овакву праксу и не би било простора за неетичко понашање.

Публикација научног рада је најважнија за начело проверљивости и јавности. Транспарентност рада подиже квалитет рада по више основа, али етички елементи су најбитнији. Када истраживач зна да ће његов рад читати 
бројна стручна и нестручна јавност, да ће свако ко буде желео моћи да има увид у то шта је урађено, да оспори и да утврђује да ли је неетички преузео заслуге за туђе дело, онда сви много обазривије приступају раду и истраживању.

Приликом објављивања рада, рад потписује само онај аутор који је допринео процесу настајања и објављивања датог научног дела. Лажно ауторство представља навођење као аутора лица које није учествовало у изради рада. Обично је у питању коаутор који се наводи из неких колегијалних односа или због постојања хијерархијског односа (надређени подређени) као што је у питању однос професор - асистент. Лажно ауторство je препознато као врста неетичког понашања у свим кодексима професионалне етике усвојеним на универзитетима у Србији и треба се борити против тога. У Кодексу понашања о научноистраживачком раду наводи се као најтежи облик преваре у науци (чл. 10, 13).

Сенат Универзитета у Београду је 2011. године донео Упутство за формирање репозиторијума докторских дисертација према коме од 2012. свака докторска дисертација мора да има следеће три изјаве које треба да буду одштампане, попуњене, потписане и приложене уз штампани и електронски примерак дисертације. То су: Изјава о ауторству, Изјава о истоветности штампане и електронске верзије и Изјава о коришћењу дисертације. Ово је постала обавеза свих универзитета у Србији од 2015. године, ступањем на снагу Закона о високом образовању. Све ове изјаве су у сагласности са етичким кодексом.

У Изјави о ауторству кандидат се изјашњава да је докторска дисертација резултат сопственог истраживачког рада, да дисертација у целини, ни у деловима није била предложена за стицање друге дипломе према студијским програмима других високошколских установа, да су резултати коректно наведени и да аутор није кршио ауторска права и користио интелектуалну својину других лица.

Изјава о коришћењу заснива се на лиценцама Кријетив комонс (Creative Commons) које штите ауторска права и дефинишу врсте власништва над ауторским делом. Докторанди треба да се изјасне како желе да се њихова дисертација води у репозиторијуму. Постоји неколико основних лиценци:

1. Ауторство (Attribution - CС ВY) - дозвољава дистрибуцију, ремикс, прераду, као и комерцијално коришћење дела, ако/док се правилно назначава име аутора. Ово је најфлексибилнија лиценца. Употребљава се како би се, у највећој мери, дозволило коришћење дела. 
2. Ауторство - Делити под истим условима (Attribution-ShareAlike CC BY-СА) - дозвољава ремикс и прераду, као и комерцијално коришћење дела, ако/док се правилно назначава име аутора и ако се прерада лиценцира под истим условима.

3. Ауторство - Без прерада (Attributio-NoDerivs - CC BY-ND) дозвољава дистрибуцију, комерцијално и некомерцијално коришћење дела, ако/док се правилно назначава име аутора и ако се дело уопште не мења.

4. Ауторство - Некомерцијално (Attribution-Noncommercial - CC BYNC) - дозвољава ремикс, прераде, као и коришћење дела на некомерцијалан начин, ако/док се правилно назначава име аутора, с тим што прераде не морају бити лиценциране овом лиценцом.

5. Ауторство - Некомерцијално - Делити под истим условима (Attribution-Noncommercial-ShareAlike - CC BY-NC-CA) - дозвољава ремикс и прераде, као и некомерцијално коришћење дела, ако/док се правилно назначава име аутора и ако се прерада лиценцира под истим условима.

6. Ауторство - Некомерцијално - Без прерада (AttributionNoncommercial-NoDerivs - CC BY-NC-ND) - најстрожа CC лиценца и дозвољава само преузимање и дистрибуцију дела, ако/док се правилно назначава име аутора, без икаквих промена дела и без права комерцијалног коришћења дела (О лиценцама Кријетив комонс 2017).

Предаја готовог рада за објављивање гарантује да рукопис представља ауторов оригиналан допринос, да није објављен раније и да се не разматра за објављивање на другом месту, односно није предат на другом месту као рад (нпр. исти семинарски рад који се подноси на разматрање у оквиру два различита предмета или исти научни рад који пролази поступак рецензије у два различита часописа). Истовремено предавање истог рукописа на више места представља кршење етичких стандарда. Могуће је објављивање истих радова у различитим часописима, али само уз сагласност уредника часописа и назнаку у ком часопису је првобитно био објављен рад (Кодекс понашања у научноистраживачком раду 2018: 4). 


\section{3. ЕТИЧКИ КОДЕКСИ НА ВИСОКОШКОЛСКИМ УСТАНОВАМА У РЕПУБЛИЦИ СРБИЈИ}

Основу за доношење свих етичких кодекса на високошколским установама у Републици Србији представља документ Основе за кодекс о академском интегритету на високошколским установама у Републици Србији, који је усвојио Национални просветни савет 2016. године. Према овом документу свака високошколска установа мора да донесе Кодекс о академском интегритету „у циљу очувања достојанства професије, унапређивање моралних вредности и подизања свести о одговорности свих чланова академске заједнице" (Основе за кодекс о академском интегритету на високошколским установама у Републици Србији 2016). Све самосталне високошколске установе биле су у обавези да донесу кодекс у складу са овим Основама у року од 45 дана од дана њиховог објављивања. Навешћемо важна документа која су усвојена на државним универзитетима у Србији као пример примене Закона:

- Универзитет у Београду је 2016. донео Кодекс професионалне етике Универзитета у Београду, Правилник о раду етичких комисија и Одбора за професионалну етику Универзитета у Београду и Правилник о поступку утврђивања неакадемског понашања у изради писаних радова. Овај Правилник се примењује на плагирање, лажно ауторство, измишљање и кривотворење резултата и аутоплагирање.

- Универзитет у Новом Саду је 2012. донео Правилник о поступку утврђивања постојања повреде кодекса професионалне етике Универзитета у Новом Саду и Кодекс о академском интегритету (пречишћен и допуњен 2020. године).

- Универзитет у Крагујевцу је донео Кодекс о академском интегритету и професионалној етиии Универзитета у Крагујевиу (2016).

- Универзитет у Новом Пазару је донео Кодекс о академском интегритету и професионалној етици.

- У Уиверзитет у Нишу је још 2009. године донео Кодекс професионалне етике Универзитета у Нишу.

- Универзитет у Приштини са седиштем у Косовској Митровици је 2008. донео Кодекс професионалне етике на Универзитету у Приштини. 
- Универзитет одбране је 2011. донео Кодекс професионалне етике на Универзитету одбране.

Национални савет за науку и технолошки развој је 2018. године донео Кодекс понашањ а у научноистраживачком раду. Овим Кодексом дефинишу се начела, етичка правила у научном раду (добра пракса коришћења података: доступност и приступ; одговарајуће истраживачке процедуре; одговорност у истраживачким поступцима; понашање током објављивања резултата истраживања; рецензија и уређивачка политика), преваре у науци (плагирање, лажно ауторство, измишљање и кривотворење резултата и аутоплагирање), органи и тела за спровођење Кодекса (Одбор за етику у науци). Важност доношења овог Кодекса огледа се у томе што предвиђа последице за неетичко понашање, као што је искључивање са научноистраживачког пројекта који се финансира из буџета. Поред овога, Кодекс напокон ставља у први план значај етичких принципа и покреће питање едукације свих студената, наставника и свих научних радника о овој важној теми.

\section{4. ПРИМЕНА У НАСТАВИ}

У овом раду представљени су етички принципи које треба да поштује сваки припадник академске заједнице. Од студената и њихових првих радова, преко наставника, професора, истраживача до институција у истраживачким пројектима колаборативног и уговорног типа. Међутим, цела област етике и правила која је прате били су годинама у домену „подразумевања”, а није постојало системско решење како би сви учесници у процесу били правилно и детаљно информисани. Један од начина упознавања је свакако читање горенаведених правилника, кодекса и закона. С друге стране, није реално очекивати од студената на почетку студија да се баве тиме; штавише, многи истраживачи их вероватно нису прочитали. Из тог разлога је Национални савет за високо образовање предвидео у Основама за кодекс о академском интегритету на високошколским установама у Републици Србији следеће:

„Високошколска установа је дужна да у току студија, а посебно на почетку прве године свих нивоа студија које организује, упозна студенте са правилима академске честитости, правилима за навођење идеја и радова других аутора, односно правилима цитирања и препричавања" (2016: 2).

Исте године је Стручни тим за реформу високог образовања у Републици Србији издао публикацију Наџионалне препоруке за универзитете 
и институте у Србији за управљање интелектуалном својином у активностима трансфера знања. У публикацији је разрађено осамнаест препорука. Једна од препорука је и подизати свест и стицати основна знања о интелектуалној својини путем обука намењених студентима и истраживачима (2016: 52).

Нажалост, и поред оваквих препорука и потреба да се уведу предмети којима би се обрађивала ова област, на високошколским установама је немогуће имати нове предмете без претходне акредитације, а често у припреми курикулума за нови циклус акредитације нема места за курсеве попут ових.

У складу са наведеним препорукама позитиван пример представља Универзитет у Београду који је за своје студенте припремио два онлајн курса о академском интегритету: Академски интегритет 1 и Академски интегритет $2^{4}$. На овим курсевима студенти се упознају са основним појмовима академске честитости и правилима академског писања. Курсеви су информативног карактера, али су од великог значаја за увођење студената у академски свет. Овакве курсеве могуће је припремити и у оквиру пројеката где би се повезале све високошколске институције зарад припреме квалитетних обука не само за студенте, већ и за све актере у терцијарном образовању.

Поред курсева и обука, факултети би требало да имплементирају и софтвер за утврђивање плагијата и омогуће приступ свом наставном особљу како би се сви студентски радови подвргли провери. Као тренутно најпопуларније комерцијално софтверско решење јавља се Турнитин (Turnitin), али постоје и бесплатни алати на интернету којима би се могли детектовати плагијати (нпр. plagiarisma.net). Формирање дигиталних репозиторијума свих студентских радова током студија такође доприноси смањењу плагијаризма. Првенствено би наставници кроз свој предмет требало да подижу свест студената о значају интелектуалне својине и значењу плагијата. а затим би и институције требало да кроз правилнике и софтверску подршку указују на важност оригиналног ауторског рада.

Свакако би препоруке ишле у овом правцу да се на свим високошколским установама успостави систем за упознавање студената са етичким принципима и академским интегритетом од самог почетка студирања, по могућности кроз засебне предмете, укључујући и оне у другом циклусу попут Методологије научних истраживања или Технике научног рада, а ако је то немогуће остварити, онда кроз понуду неформалних обука и курсева које би факултет понудио својим студентима. Требало би да наставно особље у оквиру

\footnotetext{
${ }^{4}$ Више о курсевима на http://integritet.rect.bg.ac.rs/
} 
сваког предмета упознаје студенте и доследно инсистира на етичким принципима у изради радова од првог дана студија.

\section{5. ЗАКљУЧАК}

Писање научноистраживачких радова представља дуготрајан и захтеван процес у ком је, поред стручног знања, неопходно обратити пажњу и на поштовање етичких начела како не би дошло до неетичког понашања и урушавања академског интегритета. Од 2016. године, када је Национални просветни савет донео Основе за кодекс о академском интегритету на високошколским установама у Републици Србији кодекс понашања је регулисан разним правилницима на свим државним и приватним акредитованим факултетима у Србији. Основни етички принципи поштења у научноистраживачком раду представљају следећа начела: искреност, поузданост у извођењу истраживања и објављивању резултата, објективност у тумачењу и закључивању, непристрасност и независност, отворена комуникација у дискусији са другим научницима и/или јавношћу, вођење бриге о учесницима и субјектима истраживања, исправност у навођењу референци и одговорност према будућим генерацијама научника. У овом раду представљени су кроз шест фаза у научноистраживачком процесу: фаза прикупљања литературе, фаза коришћења литературе (писање рада), фаза нацрта истраживања, фаза приступа подацима и прикупљања података, фаза обраде, анализе и интерпретације резултата и фаза обликовања и публикације научног рада. Најтежи облици преваре у науци који могу да се десе су: плагирање, лажно ауторство, измишљање и кривотворење резултата и аутоплагирање. Начело јавности (транспарентност) и начело проверљивости су најбољи начин да се спрече наведене преваре пошто врло лако може доћи до урушавања кредибилитета и академског интегритета аутора уколико није поштовао етичка начела. Уколико се утврди неакадемско понашање, доносе се мере: забрана учешћа у раду тела која су задужена за старање о квалитету научноистраживачког рада, забрана коришћења средстава за науку и истраживање, повлачење објављеног рада, опомена, јавна опомена, јавна осуда и, као најстрожи облик мере, одузимање звања, а у неким европским државама, попут Немачке, такво неетичко понашање у академском раду повлачи за собом и повлачење са јавне функције.

Иако се Кодекс понашања у научноистраживачком раду односи искључиво на научноистраживачке пројекте које финансира држава, сматрамо да су етичка начела дата у њему универзална и да треба да важе за све истраживаче који се лате израде научног рада, без обзира на то да ли су у питању 
часописи, приватни или државни сектор. Нарочиту пажњу требало би посветити едукацији и упознати све актере на високошколским установама - од студената до истраживача - о важности поштовања етичких принципа и очувања академског интегритета у процесу израде научноистраживачких радова.

\section{ЛИТЕРАТУРА}

About CC Licenses. (2017). Pristupljeno 23. 4. 2021. URL: $<$ https://creativecommons.org/about/cclicenses/>

Бјелобаба, С. (2019). Академски интегритет 1. (Курс развијен у оквиру пројекта Европске уније и Савета Европе „Јачање интегритета и борба против корупције у високом образовању у Србији” 2017-2019). Приступљено 3. 5. 2021. URL: <http://integritet.rect.bg.ac.rs/> [Bjelobaba, S. (2019). Akademski integritet 1. (Kurs razvijen u okviru projekta Evropske unije i Saveta Evrope „Jačanje integriteta i borba protiv korupcije u visokom obrazovanju u Srbiji” 2017-2019). Pristupljeno 3. 5. 2021. URL: $<$ http://integritet.rect.bg.ac.rs/>].

General Data Protection Regulation (2018). Official Journal of the European Union. Pristupljeno 23. 4. 2021. URL: 〈https://gdpr-info.eu/>

Deer, B. (2021). Andrew Wakefield: the fraud investigation. Pristupljeno 23. 4. 2021. URL: <https://briandeer.com/mmr/lancet-summary.htm>

Закон о ауторским и сродним правима (2019). Београд: Службени гласник (Службени гласник РС, бр. 104/2009, 99/2011, 119/2012, 29/2016 - одлука УС и 66/2019). Приступљено 23. 4. 2021. <http://www.mpn.gov.rs/ dokumenta-i-propisi/zakonski-okvir/> [Zakon o autorskim i srodnim pravima (2019). Beograd: Službeni glasnik (Službeni glasnik RS, br. 104/2009, 99/2011, 119/2012, 29/2016 - odluka US i 66/2019). Pristupljeno 23. 4. 2021. <http://www.mpn.gov.rs/dokumenta-i-propisi/zakonski-okvir/>].

Закон о заштити података о личности (2018). Приступљено 23. 4. 2021. URL: <https://www.paragraf.rs/propisi/zakon_o_zastiti_podataka_o_licnosti.html> [Zakon o zaštiti podataka o ličnosti (2018). Pristupljeno 23. 4. 2021. URL: <https://www.paragraf.rs/propisi/zakon_o_zastiti_podataka_o_licnosti.html>].

Закон о научноистражсивачкој делатности (2005). Београд: Службени гласник (Службени гласник РС, бр. 110/2005, 50/2006 - испр., 18/2010 и 112/2015) Приступљено 23. 4. 2021. URL: <http://www.mpn.gov.rs/ dokumenta-i-propisi/zakonski-okvir/> [Zakon o naučnoistraživačkoj delatnosti (2005). Beograd: Službeni glasnik (Službeni glasnik RS, br. 
110/2005, 50/2006 - ispr., 18/2010 i 112/2015) Pristupljeno 23. 4. 2021. URL: <http://www.mpn.gov.rs/dokumenta-i-propisi/zakonski-okvir/>].

Илић, В. (2016). Посматрање и анализа садржаја. Београд: Филозофски факултет. [Ilić, V. (2016). Posmatranje $i$ analiza sadržaja. Beograd: Filozofski fakultet]..

Јовановић, М. Б. (2010). Упутство за писање и презентирање научних $и$ стручних радова Приступљено 23. 4. 2021. URL: $<$ https://www.grf.bg.ac.rs/ mjovanovic/gal-sr.html> [Jovanović, M. B. (2010). Uputstvo za pisanje $i$ prezentiranje naučnih $i$ stručnih radova. Pristupljeno 23. 4. 2021. URL: <https://www.grf.bg.ac.rs/ mjovanovic/galsr.html>].

Клајн, И., Шипка, М. (2007). Велики речник страних речи и израза. Нови Сад: Прометеј. [Klajn, I., Šipka, M. (2007). Veliki rečnik stranih reči i izraza. Novi Sad: Prometej].

Кодекс о академском интегритету (2020). Сенат Универзитета у Новом Саду. Приступљено 23. 4. 2021. URL: <https://www.uns.ac.rs/index.php/ univerzitet/javnost-rada-2/dokumenti/aktiuns/category/35-pravilnici/> [Kodeks o akademskom integritetu (2020). Senat Univerziteta u Novom Sadu. Pristupljeno 23. 4. 2021. URL: <https://www.uns.ac.rs/index.php/ univerzitet/javnost-rada-2/dokumenti/aktiuns/category/35-pravilnici/>].

Кодекс понашања у научноистраживачком раду (2018). Национални савет за науку и технолошки развој. Приступљено 23. 4. 2021. URL: <http://www.mpn.gov.rs/tela-i-komisije/> [Kodeks ponašanja u naučnoistraživačkom radu (2018). Nacionalni savet za nauku i tehnološki razvoj. Pristupljeno 23. 4. 2021. URL: <http://www.mpn.gov.rs/tela-ikomisije/>].

Ljubojević, D. (2018). GDPR and Learning Management Systems. Proceedings / The Ninth International Conference on e-Learning: 15-19. Pristupljeno 23. 4. 2021. URL: 〈http://econference.metropolitan.ac.rs>

Милић, В. (1996 (1965)). Социолошки метод. Београд: Завод за уџбенике. [Milić, V. (1996 (1965)). Sociološki metod. Beograd: Zavod za udžbenike].

Милић, Н. (2021). Цитирање литературе у научном раду. Приступљено 23. 4. 2021. URL: Универзитетска библиотека Светозар Марковић: $<$ https://unilib.libguides.com/c.php?g=660502\&p=4664158> [Milić, N. (2021). Citiranje literature u naučnom radu. Pristupljeno 23. 4. 2021. URL: <Univerzitetska biblioteka Svetozar Marković: https:/unilib.libguides.com/ c.php?g=660502\&p=4664158>]. 
Миљевић, М. И. (2007). Методологија научног рада. Пале: Филозофски факултет, Универзитет у Источном Сарајеву. [Miljević, M. I. (2007). Metodologija naučnog rada. Pale: Filozofski fakultet, Univerzitet u Istočnom Sarajevu].

Наиионалне препоруке за универзитете и институте у Србији за управљање интелектуалном својином у активностима трансфера знања (2016). Стручни тим за реформу високог образовања у Републици Србији. Београд: Фондација Темпус. [Nacionalne preporuke za univerzitete $i$ institute $u$ Srbiji za upravljanje intelektualnom svojinom $u$ aktivnostima transfera znanja (2016). Stručni tim za reformu visokog obrazovanja u Republici Srbiji. Beograd: Fondacija Tempus].

Одбор за професионалну етику (2019). Решење Одбора за професионалну етику донето на седници од 21. 11. 2019. године. Приступљено 23. 4. 2021. URL: <Универзитет у Београду: http://bg.ac.rs/sr/organi/etika/etika.php> [Odbor za profesionalnu etiku. (2019). Rešenje Odbora za profesionalnu etiku doneto na sednici od 21. 11. 2019. godine. Pristupljeno 23. 4. 2021. URL: <Univerzitet u Beogradu: http://bg.ac.rs/sr/organi/etika/etika.php>].

Основе за кодекс о академском интегритету на високошколским установама у Републици Србији (2016). Национални савет за високо образовање. Приступљено 23. 4. 2021. URL: 〈http://nsvo.gov.rs/одлуке-нсво/> [Osnove za kodeks o akademskom integritetu na visokoškolskim ustanovama u Republici Srbiji (2016). Nacionalni savet za visoko obrazovanje. Pristupljeno 23. 4. 2021. URL: <http://nsvo.gov.rs/odluke-nsvo/>].

Roščić, D. (2013). Ministarki oduzeta doktorska titula. DW, 2. jun. Pristupljeno 23. 4. 2021. URL: <https://p.dw.com/p/17Yvo>

Стојшин, С. (2014). Интернет као предмет истраживања и/или средство за прикупљање података - са освртом на електронски упитник. Интернет и друштво: међународни тематски зборник радова: 197-214. Приступљено 23. 4. 2021. URL: 〈http://iup.rs/books/internet-i-drustvo/> [Stojšin, S. (2014). Internet kao predmet istraživanja $\mathrm{i} / \mathrm{ili}$ sredstvo za prikupljanje podataka - sa osvrtom na elektronski upitnik. Internet i društvo: međunarodni tematski zbornik radova: 197-214. Pristupljeno 23. 4. 2021. URL: <http://iup.rs/books/internet-i-drustvo/>].

Tkalac Verčič, A., Sinčić Ćorić, D., Pološki Vokić, N. (2010). Priručnik za metodologiju istraživačkog rada : Kako osmisliti, provesti i opisati znanstveno i stručno istraživanje. Zagreb: M. E. P. d. o. o. 
Filipović, S. (2011). Gutenberg grubo prekršio standarde. $D W, 11$. maj. Pristupljeno 23. 4. 2021. URL: 〈https://p.dw.com/p/11DpS>

Fundamental Values of Academic Integrity, Third Edition (2020). Pristupljeno 3. 5. 2021. URL: <https://www.academicintegrity.org/fundamental-values/>

Danijela D. Ljubojević

Belgrade Metropolitan University

Faculty of Information Technologies

\section{ETHICAL PRINCIPLES AND ACADEMIC INTEGRITY IN PREPARING SCIENTIFIC RESEARCH PAPERS FOR PUBLICATION}

\section{Summary}

Writing scientific and research papers is a long and demanding process in which, in addition to professional knowledge, it is necessary to respect ethical principles and to act with academic integrity. Ethical principles can be violated in each of the phases in the scientific research process if the code of ethical behaviour is not known or is intentionally neglected. These principles are given throughout the valid regulations in the Republic of Serbia adopted at the level of the entire country and at the level of higher education institutions whose obligation was to harmonize their acts with the Fundamentals of the Code of Academic Integrity at higher education institutions in the Republic of Serbia, adopted by National Education Council in 2016. The basic ethical principles presented in this paper are the following: honesty, reliability in conducting research and publishing results, objectivity in interpretation and conclusion, impartiality and independence, open communication in discussion with other scientists and / or the public, caring for participants and research subjects, correctness in quoting references, and responsibility towards future generations of scientists. They are presented through six phases: the phase of collecting literature; the phase of using literature (writing a paper); the research design phase; the data access and data collection phase; the phase of processing, analysis and interpretation of results; and the phase of shaping and publishing a scientific paper. The most serious forms of offences in science are plagiarism, false authorship, fabrication and falsification of results, and self-plagiarism. The principle of publicity (transparency) and the principle of verifiability are the best ways to prevent these offences, as they can very easily lead to the damage of the credibility and academic integrity of the author if (s)he did not respect ethical principles.

Key words: ethical principles, higher education institutions, phases in writing a scientific paper, citation, plagiarism, auto-plagiarism, false authorship, fabrication and falsification of results.

Примљено: 15. 5. 2021.

Прихваћено: 30. 8. 2021. 